\title{
アルミナー鉄複合体のホットプレス焼結とその諸特性
}

\author{
岩佐美喜男・木下実・渡辺隆司*・坂口景三*

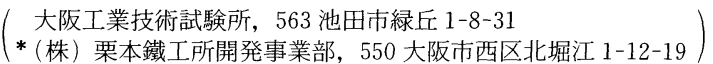

\section{Hot-Pressing of Alumina-Iron Composite Ceramics and Their Properties}

\author{
Mikio IWASA, Makoto KINOSHITA, Takashi WATANABE* and Keizo SAKAGUCHI* \\ $\left(\begin{array}{c}\text { Government Industrial Research Institute, Osaka, Midorigaoka 1-chome, Ikeda-shi } \\ \text { * Development Section, Kurimoto Ltd., 12-19, Kitahorie 1-chome, Nishi-ku, Osaka-shi }\end{array}\right.$
}

\begin{abstract}
Alumina-iron composite ceramics were fabricated by hot-pressing from well mixed alumina and iron powders at $1550^{\circ} \mathrm{C}$ and $300 \mathrm{kgf} / \mathrm{cm}^{2}$ for $30 \mathrm{~min}$. Sintered bodies with nearly theoretical density were obtained for addition of less than $20^{\circ}$ wt $\% \mathrm{Fe}$, but the relative density decreased gradually with increasing $F$ e content more than that. The alumina-iron composites showed more extensive grain growth than pure alumina, and there were many open spaces around iron grains generated by the thermal expansion mismatch. The fracture toughness increased with increasing $\mathrm{Fe}$ content, reaching $4 \mathrm{MN} / \mathrm{m}^{3 / 2}$ at 50 wt\% Fe. The Vickers hardness, on the other hand, decreased rapidly around 10 wt\% Fe addition. The specific wear rate measured on a sintered alumina disk increased with increasing Fe content, but was lower than $10^{-7} \mathrm{~mm}^{2} / \mathrm{kgf}$ at 40 wt\% Fe, which is comparable to that of dense silicon nitride ceramics. The cutting resistance was reduced significantly by Fe addition. Especially, the tangential resistance of $\mathrm{Al}_{2} \mathrm{O}_{3}-30$ wt\% $\mathrm{Fe}$ composite was lower than that of pure alumina by the factor of 10 . The iron which existed near the surface of composite was removed in the first few minutes when treated in boiling $\mathrm{H}_{2} \mathrm{SO}_{4}$, but no subsequent weight loss was observed. The fracture strength of the composite decreased gradually up to $600^{\circ} \mathrm{C}$, and then rapidly at higher temperature.

[Received October 1, 1987; Accepted December 15, 1987]
\end{abstract}

Key-words : Alumina-Iron composite, Hot-press, Fracture toughness, Vickers hardness, Wear rate, Cutting resistance, Chemical durability, Elevated temperature strength

\section{1. 緒言}

一般にセラミックスは, 高温での強度, 耐酸化性, 薬 品に対する耐腐食性, 耐摩耗性等, 各種の物理的・化学 的特性に優れた材料であり, 次世代産業における重要な 新素材として注目を集めている. しかし, その反面, セ ラミックスはぜい性材料であり, 切削等の加工が困難で あるなど, 克服しなければならない課題も多いと言え る1!.

数多くのセラミックスの中でも, アルミナは原料コス 卜が安く, 大気中で焼結が可能であるので焼結設備も比 較的簡易であり, 最も多用されている材料である ${ }^{2\}}$. そ こで, アルミナのセラミックスとしての特性を損なうこ となく, ぜい性や難加工性といった問題点を改善する方 法について検討した。一般に, 金属はセラミックスに比 ベると塑性変形性や加工性に優れているので31，両者を 混合して焼結すれば，七ラミックスの靶性や加工性が向 上することが期待される．金属材料のなかでも，アルミ ナとの反応性や熱膨張係数の大きさ, 原料コス卜などを も考慮して，添加する金属には鉄を選択した。

アルミナと鉄の粉末を混合し，ホットプレス法によっ て, 複合焼結体を作製した. そして, その組織, 硬さ, 靯性等の基本的な特性, 更には, 研削抵抗, 耐腐食性,
高温強度等の奏用的な諸特性についても検討した。

\section{2. 実験方法}

\section{1 試料の作製}

アルミナ $\left(\mathrm{Al}_{2} \mathrm{O}_{3}\right)$ 粉末としては, 平均粒径が約 0.4 $\mu \mathrm{m}$ で, 異常粒成長抑制等のために $\mathrm{MgO}$ が $0.1 \%$ 添加 されている易焼結性アルミナ（住友化学工業製, AES-11) を用いた. AES-11 に所定割合の鉄粉末（福 田金属箔粉工業製，Fe-S，200 mesh）を添加し，エチ ルアルコールを加えてアルミナボールミルで 24 時間, 湿式混合した。 そのスラリーを真空吸引沪過, 乾燥した 後, 再び乳鉢で粉砕, 混合し, ホットプレスの出発原料 とした．内側形状が $40 \times 20 \mathrm{~mm}$ の黒鉛型に，完全にち 密化すれば厚さ $8 \mathrm{~mm}$ になるように, この粉末の所定量 を充填した. ホットプレス焼結は, $300 \mathrm{kgf} / \mathrm{cm}^{2}$ の圧力 を加え，高周波誘導により所定温度まで加熱，30 分間 保持した4).

まず，複合体の最適な焼結温度を決定するために，鉄 添加量を $10 \mathrm{wt} \%$ と固定し，鉄の融点なども考慮し，木 ットプレス温度を $1200^{\circ} \sim 1700^{\circ} \mathrm{C}$ 間で $100^{\circ} \mathrm{C}$ おきに設 定して, 予備実験を行った. そして, 3.1 節で詳しく述 べるように，最適を焼結温度を $1550^{\circ} \mathrm{C}$ と決定し，同条 
件で鉄添加量を 0，5，10，20，30，40，及び 50 wt\% の七通りに設定した本実験を行うこととした.

黒鉛型より取り出した試料は各面をダイヤモンド砥石 （\#200）により平面研削し, 以下の測定に供した.なお, 各実験条件について試料は 3 個ずつ作製した.

\section{2 各種物性の測定}

各試料の密度は蒸留水中でのアルキメデス法により測 定した。各試料から JIS R 1601-1981に準ずる形状の 強度試験片を切り出し, CSF 法により破壊靶性 $\left(K_{\mathrm{IC}}\right)$ を測定した で導入し, 強度はスパン $30 \mathrm{~mm}$, クロスヘッドスピー ド $0.5 \mathrm{~mm} / \mathrm{min}$ の 3 点曲げとした. 試料面を鏡面研磨 して, ビッカース硬度 $\left(H_{\mathrm{v}}\right)$ を測定した。荷重 5 20 $\mathrm{kgf}$ を 30 秒間印加し, 数点の平均值を採った. 試料面 をそのままでX 線回折を行い, 結晶相を調べた，X線 源としては $\mathrm{Cu} K \alpha$ 線を用い, 加速電圧 $35 \mathrm{kV}$, 管電流 $15 \mathrm{~mA}$ ，ゴニオメーターの送り速度 $1 \%$ min で測定した. 走査型電子顕微鏡 (SEM) により試料破断面の組織観 察を行った ${ }^{6)}$.

\section{3 摺動摩耗試験}

鉄の添加によるアルミナの摩耗特性の変化を調べるた め, ピンオンディスク法による摺動摩耗試験を行った ${ }^{71}$. ダイヤモンドカップ砥石（\#200）で, 破壊靶性測定後 の試験片の先端を半径約 $2 \mathrm{~mm}$ の半球状に加工し, ピン 試料とした．相手ディスクには形状 $60 \phi \times 10 \mathrm{~mm}$ のア ルミナ焼結体（日本化学陶業製, SSA-S）を用い，摺 動条件としては, 押付荷重を $1 \mathrm{kgf}$, 摺動速度を 17.5 $\mathrm{cm} / \mathrm{s}$ （摺動円直径 $50 \mathrm{~mm}$, 回転数 $67 \mathrm{rpm}$ ) とし, 常温, 大気中で測定した. 摩耗量は試験片の重量减少より求め, 単位押付荷重, 単位摺動距離当たりの摩耗体積, すなわ ち比摩耗量 $\left(W_{\mathrm{s}}\right)$ で表現した.

\section{4 研削抵抗の測定}

各試料の加工性を評価する方法として研削抵抗を測定 した. 平面研削盤 (岡本工作機械製, ASM-3 G) の電 磁チャックにキスラ一動力計を取り付け, その上に形状 $40 \times 20 \times 8 \mathrm{~mm}$ の直方体試料を固定する. 切断用ダイヤ モンドホイール (サイズ $150^{D} \times 1^{T} \times 3^{X}$, 砥粒 SD 140-100 B) により, 切り込み深さ $2.5 \mathrm{~mm}$, 周速度 31 $\mathrm{m} / \mathrm{s}$, 送り速度 $80 \mathrm{~mm} / \mathrm{min}$ という条件で, 水で冷却し ながら試料を長手方向に切断する. そのとき, 動力計に 加わる水平及び垂直方向の分力を測定, 記録し, 切断部 分での平均的な接線及び法線方向研削抵抗を計算し

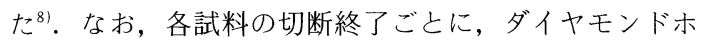
イールはホワイトコランダム (WA 200 G) でドレッシ ングを施した。

\section{5 而腐食性試験}

これらの複合焼結体では, 水分や酸, アルカリなどに よる鉄分の酸化や腐食が心配される，そこで，沸騰硫酸
による腐食試験を行った。試料表面積を一定にするため に，形状 $20 \times 7 \times 4 \mathrm{~mm}$ の試験片を準備した．5\%の硫 酸を $200 \mathrm{ml}$, 硫酸濃度が変化しないように玉型還流冷 却器を取り付けた三ツ口丸底フラスコ（容量 $500 \mathrm{ml}$ ) に入れ, マントルヒーターで加熱, 沸騰させる. そこへ, アセトンで十分洗浄した試験片を投入し, 所定時間放置 した. 硫酸処理前後の試験片重量を測定し，その単位表 面積あたりの減少量で而腐食性を評価した。

\section{6 高温曲げ強度の測定}

本複合焼結体では高温になると鉄の軟化による強度劣 化が予想されるので，シリコニット電気炉を有する強度 試験機により, 高温強度を測定した。所定温度の電気炉 に試料を挿入し 10 分間保持してから，スパン $20 \mathrm{~mm}$, クロスヘッドスピード $0.5 \mathrm{~mm} / \mathrm{min}$ の条件で 3 点曲げ 強度を測定した。

\section{3. 結 果}

\section{1 予備実験}

アルミナー鉄複合体に最適な焼結温度を決めるために， まず，鉄添加量を $10 \mathrm{wt} \%$ と固定して，ホットプレス温 度を $1200^{\circ} \sim 1700^{\circ} \mathrm{C}$ の間で変化させた．複合焼結体の密 度のホットプレス温度による変化を図 1 に示した。 $1200^{\circ} \mathrm{C}$ では, $20 \%, 1300^{\circ} \mathrm{C}$ では $5 \%$ 程度の気孔を含む が， $1400^{\circ} \mathrm{C}$ 以上ではほぼ理論密度までち密化している. 次に，複合体の破壊勒性に対するホットプレス温度の影 響を表したのが図 2 である．破壊靶性は温度とともに増 加し, $1500^{\circ} \mathrm{C}$ で $3 \mathrm{MN} / \mathrm{m}^{3 / 2}$ に達するが, それ以上の温 度では若干減少気味となる。

鉄の融点が $1530^{\circ} \mathrm{C}$ 付近であることなども考慮し，こ れらの結果から，ち密で高鞁性な焼結体を得るのに最適 なホットプレス温度は $1550^{\circ} \mathrm{C}$ 付近であると推定され

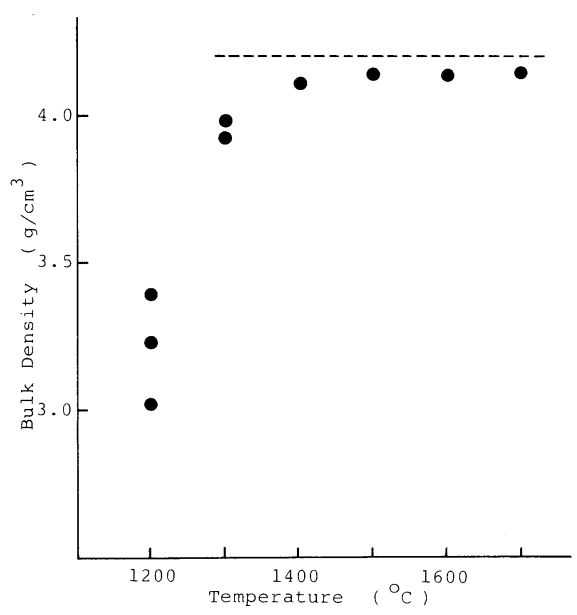

Fig. 1. The bulk densities of $\mathrm{Al}_{2} \mathrm{O}_{3}-10$ wt $\%$ Fe composite ceramics as a function of hot-pressing temperature. The dotted line indicates the thoretical density. 


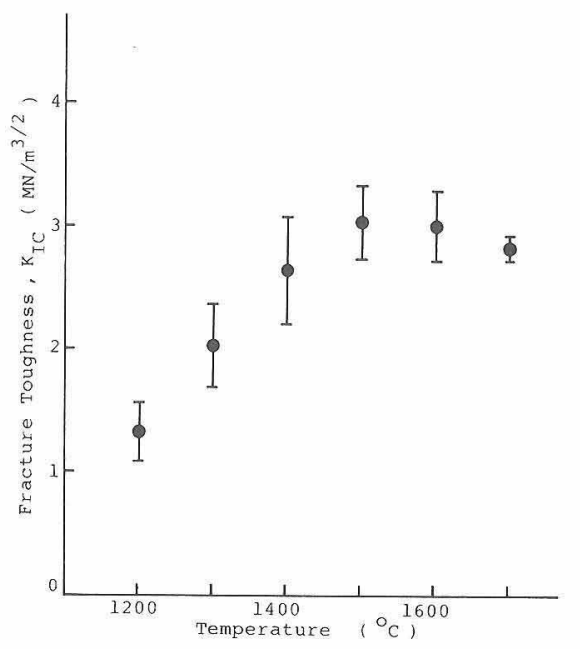

Fig. 2. The fracture toughness of composite ceramics measured by CSF method as a function of hot-pressing temperature.

A1 203

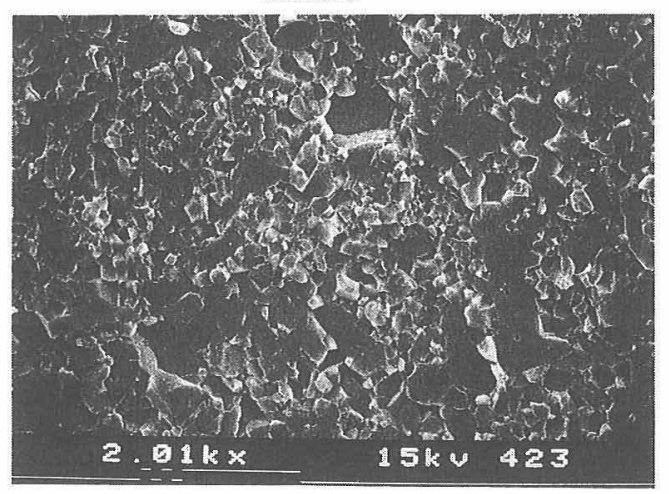

$20 w t: F e$

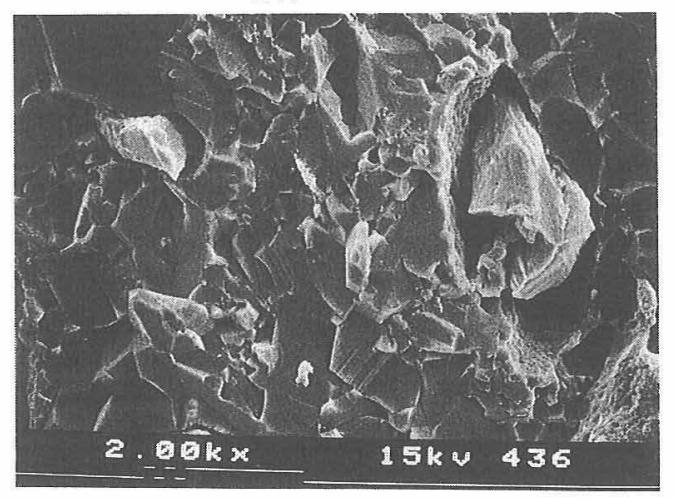

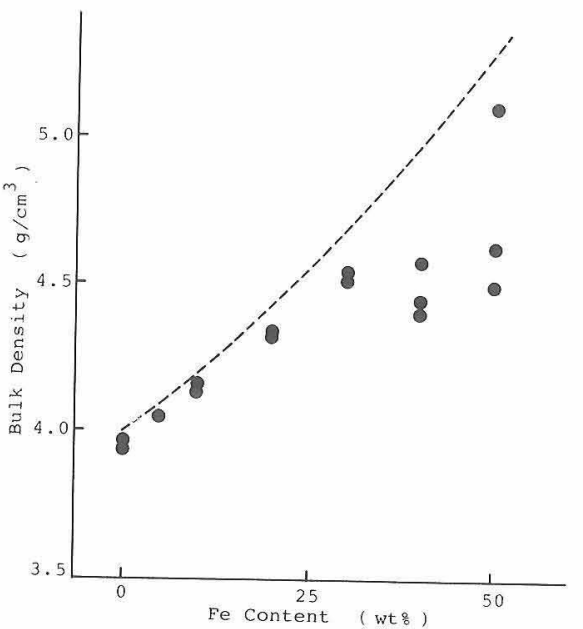

Fig. 3. The variation of bulk densities with $\mathrm{Fe}$ content. The hot-pressing condition was $1550^{\circ} \mathrm{C}, 300 \mathrm{kgf} / \mathrm{cm}^{2}$ for $30 \mathrm{~min}$.

lowt $\% \mathrm{Fe}$

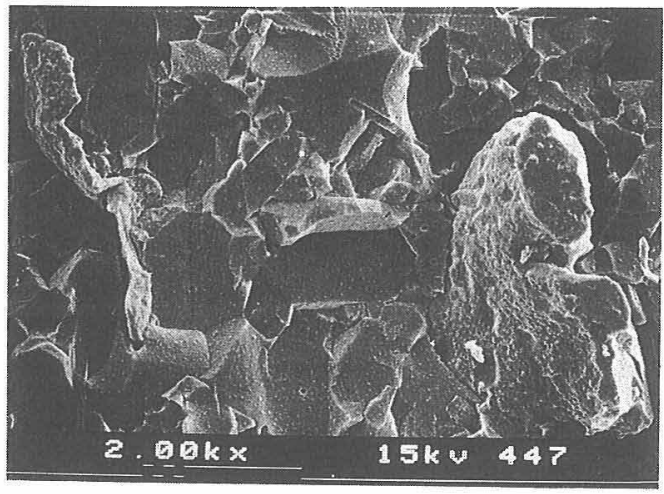

$40 w t \div \mathrm{Fe}$

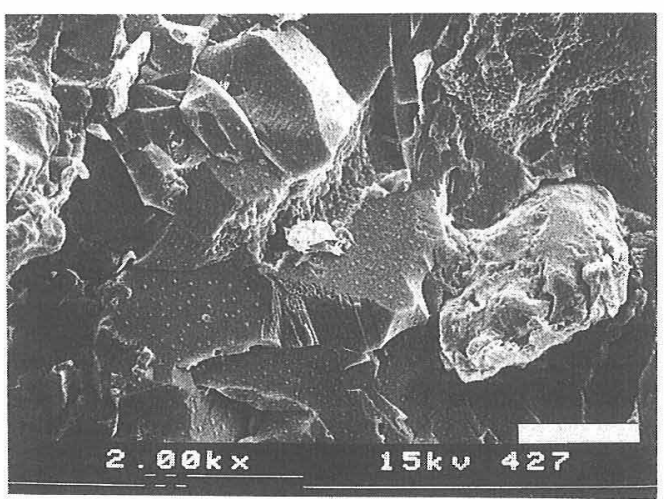

Fig. 4. The fractured surfaces of $\mathrm{Al}_{2} \mathrm{O}_{3}$ and $\mathrm{Al}_{2} \mathrm{O}_{3}-\mathrm{Fe}$ composite ceramics. The bars represent $10 \mu \mathrm{m}$.

る.もちろん，鉄の含有量が変化すれば，その最適温度 も変化する可能性は否定できないが，一応，ホットプレ ス条件は温度 $1550^{\circ} \mathrm{C}$, 圧力 $300 \mathrm{kgf} / \mathrm{cm}^{2}$, 保持時間 30 分間として, 以下の本実験を行うこととした。

\section{2 複合焼結体の密度}

鉄の添加量を 0 50 wt％まで変化させたアルミナの 密度を図 3 に示した。図中の破線はアルミナ ( $\mathrm{X}$ 線密 度 $3.99 \mathrm{~g} / \mathrm{cm}^{3}$ ) と鉄 (同じく7.88 g/ $\mathrm{cm}^{3}$ ) の単純な混 
合体とした理論密度を表しているが，鉄添加量が 20 wt％までは理論密度近くまでち密化している.しかし， 鉄添加量が 30 wt \% を超えると, 次第に相対密度は低下 し，鉄 $50 \mathrm{wt} \%$ は $20 \%$ 近い気孔を含むようになる。こ のように, 多量の鉄の添加はアルミナの焼結ち密化を阻 害するようである。

\section{3 組織観察}

図 4 にアルミナ単味, 及び鉄を添加した焼結体の破断 面の走査型電子顕微鏡 (SEM) 写真を示した。アルミ ナ単味では数 $\mu \mathrm{m}$ である結晶粒径が, 鉄を添加すること により，10 $\mu \mathrm{m}$ 以上までかなり大きく成長している．図 中でより明るく見える大きな粒子が鉄であり，そのまわ りには幾らかの幅を持った空間が存在する.これは鉄の 熱膨張がアルミナより大きいために, ホットプレス後の 冷却の過程で発生すると考えられる. 鉄を多量に含む焼 結体ではアルミナ粒界に小さな斑点が多数見られ, 一部 溶融した鉄，あるいはその反応物が粒界に存在している のではないかと思われる.

\section{$3.4 \mathrm{X}$ 線回折}

複合体の焼結中に鉄とアルミナが反応しないかを調べ るために，X線回折を行い，その結果を図５に示した. $\mathrm{X}$ 線源に $\mathrm{Cu} K \alpha$ 線を使用したため, 鉄のバックグラウ ンドが鉄の添加量とともに高くなっているが，いずれも $\alpha-\mathrm{Al}_{2} \mathrm{O}_{3}(\mathrm{JCPDS} 10-173)$ と $\alpha-\mathrm{Fe}(\mathrm{JCPDS} 6-0696)$ 以 外のピークは確認されず, 鉄とアルミナはほとんど反応 していないと考えられる.

\section{5 破壊靫性}

破壊靶性の鉄添加量による変化を図 6 に示した.アル ミナ単味の $K_{\mathrm{IC}}=2.6 \mathrm{MN} / \mathrm{m}^{3 / 2}$ から, 鉄添加量とともに
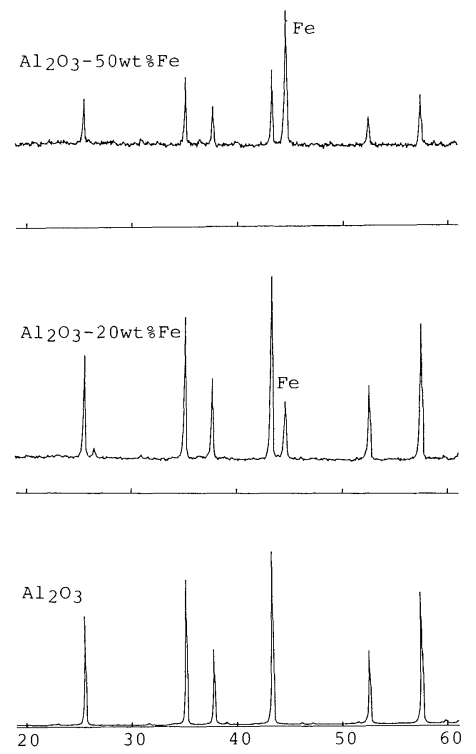

Fig. 5. The X-ray diffraction patterns of composite ceramics with various $\mathrm{Fe}$ content.
増加し，鉄 $50 \mathrm{wt} \%$ では $K_{\mathrm{IC}}=4 \mathrm{MN} / \mathrm{m}^{3 / 2}$ 近くに達して いる.

\section{6 ビッカース硬度}

図 7 に示すように，アルミナ単味及び鉄 $5 \mathrm{wt} \%$ まで のビッカース硬度は $H_{\mathrm{v}}=1900 \mathrm{kgf} / \mathrm{mm}^{2}$ であるが，鉄の 添加量が 10 wt \% あたりで急速な低下を示し，鉄 20 $\mathrm{wt} \%$ 以上では $H_{\mathrm{v}}=800 \sim 900 \mathrm{kgf} / \mathrm{mm}^{2}$ の範囲でやや低 下の傾向にある。

\section{7 摺動摩耗特性}

アルミナ焼結体ディスクに対する比摩耗量の鉄添加量 による変化を図 8 に示した，複合焼結体の比摩耗量は鉄

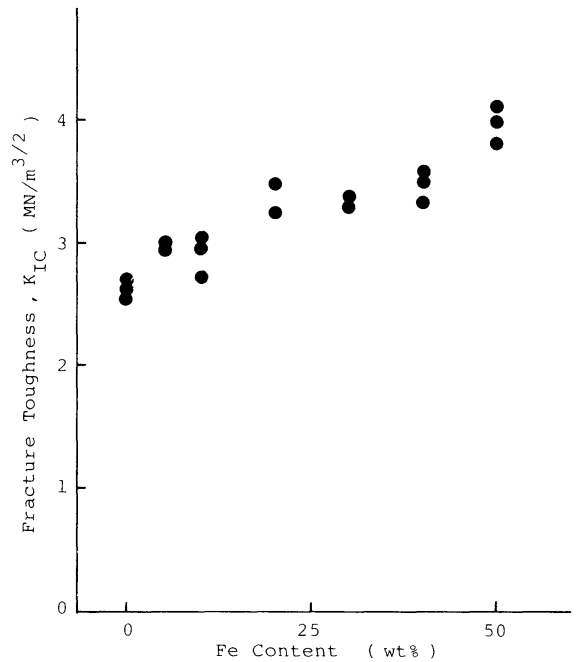

Fig. 6. The fracture toughness of composite ceramics as a function of $\mathrm{Fe}$ content.

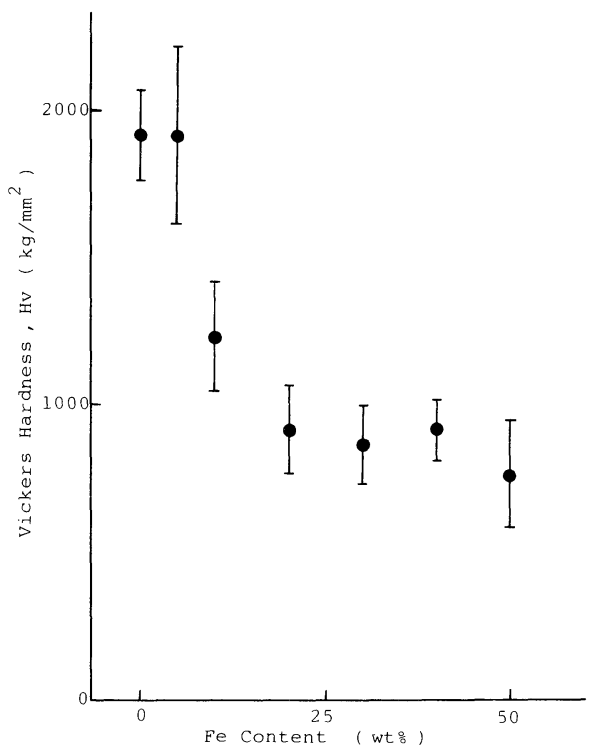

Fig. 7. The Vickers hardness of composite ceramics as a function of $\mathrm{Fe}$ content. 


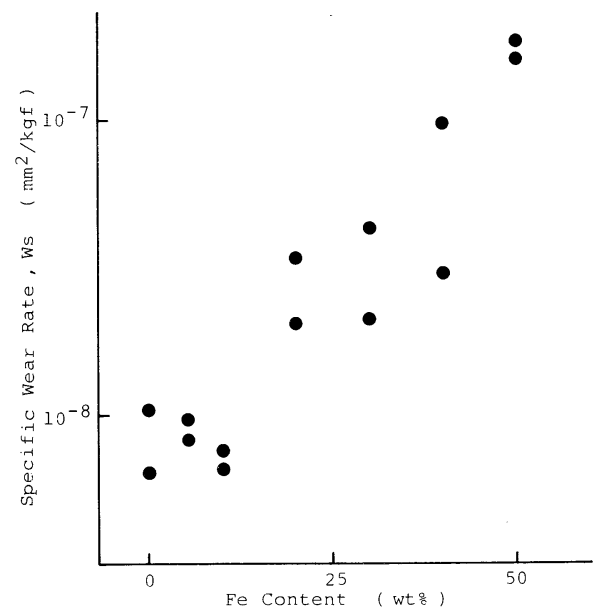

Fig. 8. The specific wear rate of composite ceramics sliding on $\mathrm{Al}_{2} \mathrm{O}_{3}$ disk at load of $1 \mathrm{kgf}$ and sliding velocity of $17.5 \mathrm{~cm} / \mathrm{s}$.
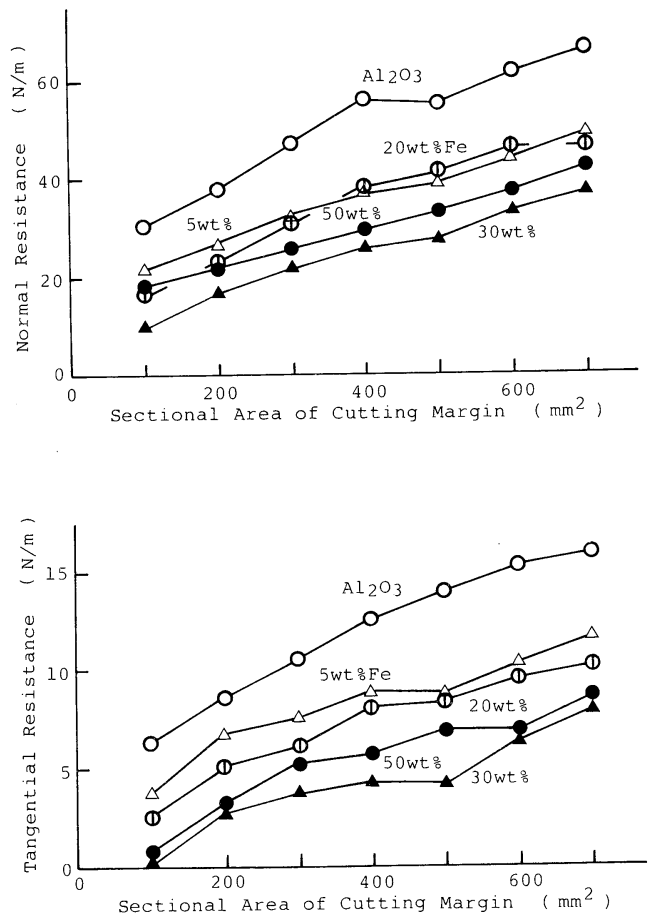

Fig. 9. The cutting resistance in tangential and normal directions of composite ceramics with various content of $\mathrm{Fe}$ as functions of sectional area of cutting margin.

添加量とともにかなり急速に増加しているが, 鉄添加量 $40 \mathrm{wt} \%$ まででは, ち密に焼結された窒化ケイ素に匹敵 する $10^{-7} \mathrm{~mm}^{2} / \mathrm{kgf}$ 以下の比摩耗量であった ${ }^{91}$.

\section{8 研削抵抗}

各複合焼結体の切断試験において測定された, 接線方 向及び法線方向の研削抵抗を図 9 に示した. 横軸は切断 代断面積であり, 縦軸は単位切断幅あたりの研削抵抗の
大きさである.アルミナ単味に比べて，鉄を添加した焼 結体の研削抵抗はかなり低く, 特に鉄を $30 \mathrm{wt} \%$ 添加し た試料が最も低い研削抵抗を示している. また，切断代 断面積が増加するに従って, 研削抵抗の值はいずれの試 料でも同じような傾向で増大している.なお，鉄を 30 wt \% 添加した試料の接線方向の研削抵抗はアルミナ単 味に比較して $1 / 10$ 程度と極めて小さな值を示している ので, 再現性を確認するために, 切断代断面積が 100 $\mathrm{mm}^{2}$ を超えるごとにダイヤモンドホイールの再ドレッ シングをしながら， $700 \mathrm{~mm}^{2}$ までの測定を行った．その 結果, 接線及び法線方向の研削抵抗は最初亡同じ值に復 帰することが確認された。

\section{9 耐腐食性}

鉄 $20 \mathrm{wt} \%$ の複合焼結体について，5\%の沸騰硫酸に 対する腐食試験を行った結果を図 10 に示した。図から わかるように，最初の数分間で単位表面積あたり $3 \sim 4$ $\mathrm{mg} / \mathrm{cm}^{2}$ の鉄が溶出するようであるが, それ以上の処理 時間における重量減少はほとんど認められなかった。

\subsection{0 高温曲げ強度}

3.9 節と同じ鉄 $20 \mathrm{wt} \%$ の複合焼結体について, 高温 3 点曲げ試験を行った結果が図 11 である.アルミナー

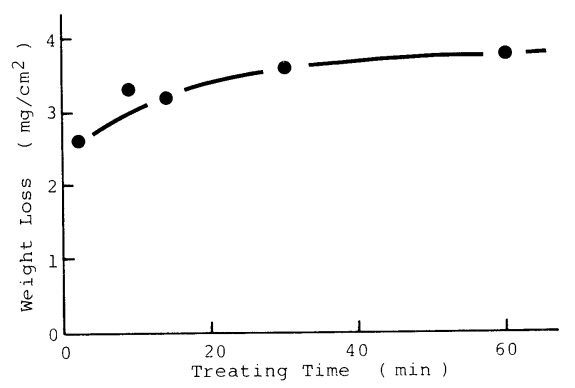

Fig. 10. The weight loss of $\mathrm{Al}_{2} \mathrm{O}_{3}-20$ wt $\%$ Fe composite ceramics with treating time in boiling $5 \% \mathrm{H}_{2} \mathrm{SO}_{4}$.

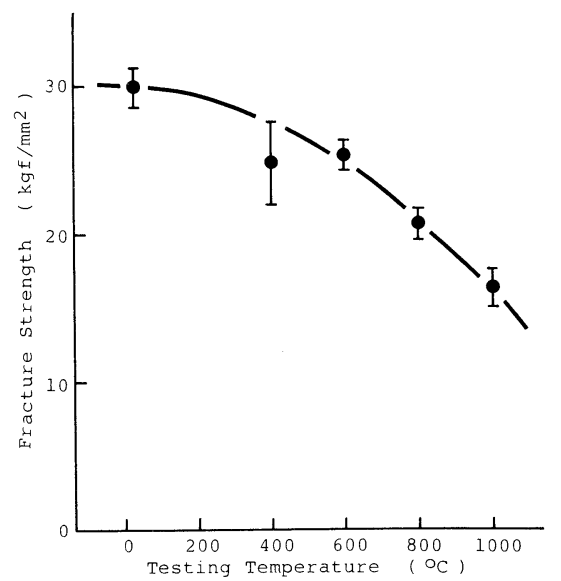

Fig. 11. The fracture strength of $\mathrm{Al}_{2} \mathrm{O}_{3}-20$ wt $\% \mathrm{Fe}$ composite ceramics as a function of testing temperature up to $1000^{\circ} \mathrm{C}$. 
鉄複合体の強度は試験温度 $600^{\circ} \mathrm{C}$ まで徐々に, そして それ以上の温度ではやや急速に劣化している．アルミナ 単味と比較すると, 高温強度特性はやや劣っているよう である．やはり，鉄の軟化が原因であるとみられる。

\section{4. 考 察}

アルミナの破壊靶性や機械加工性を改善する目的で, 鉄粉末を添加した複合焼結体をホットプレス法により作 製した. 図 3 の鉄添加量による密度変化の結果からわか るように，鉄 $40 \mathrm{wt} \%$ 以上ではかなり相対密度が低く なっている．これは鉄がち密化を阻害すること以外に， 鉄の融点を超える $1550^{\circ} \mathrm{C}$ でホットプレスしているた め, アルミナ粒子間に溶融した鉄をすべては保持できな くなり，一部流出してしまうのも原因と思われる．ち密 な複合体の作製には，鉄添加量によりホットプレス条件 の変更も必要であろう.

破壊鞁性 $\left(K_{\mathrm{IC}}\right)$ はクラックサイズを $c$, 破壊強度を $\sigma_{\mathrm{f}}$, 形状因子を $Y$ として，

$$
K_{\mathrm{IC}}=Y \sigma_{\mathrm{f}} \sqrt{c}
$$

と表され，七ラミックスのクラックに対する耐性の尺度 と考えられている. 図6に示すように鉄の添加によりア ルミナの $K_{\mathrm{IC}}$ はかなり向上している，ところで，参考の ために測定したアルミナ単味の曲げ強度は $35 \mathrm{kgf} / \mathrm{mm}^{2}$, 鉄 $20 \mathrm{wt} \%$ では $30 \mathrm{kgf} / \mathrm{mm}^{2}$ 程度と若干低下している。 これらの值から（1）式を用いて計算されるクラックサ

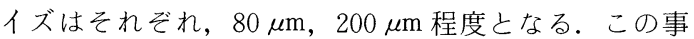
実は図 4 からもわかるように添加した鉄粉末の粒子がか なり大きいので, 内在するクラックもアルミナ単味に比 ベて大きいと理解される，セラミックスを機械構造材料 として使用する場合, 固体接触や粉体の衝突などによっ て導入される微小なクラックによる強度低下が大きな問 題点亡されている.今回のアルミナー鉄複合焼結体には もともと大きなクラックが内在しているので，そのよう な加傷の影響が比較的少ない材料になりうることが期待 される.

セラミックスの加工性については, 特に接線方向の研 削抵抗が重要であると考えられる。すなわち，法線方向 の抵抗は一定の条件で研削加工する際に，どれだけの力 で押し付ける必要があるかを示しているのに対し，接線 方向の抵抗はダイヤモンドホイールの回転トルクに対す る正味の抵抗となるからである。アルミナ単味に比べて アルミナ-鉄複合体の研削抵抗は低く, 特に鉄 $30 \mathrm{wt} \%$ 添加の試料の接線方向の抵抗は極めて低く，非常に優れ た加工性を示していると言える. 図4にみられる，鉄と アルミナの熱膨張の差によって生じた鉄粒子周囲の空間 も研削抵抗改良の一因之思われる. 図 9 において切断代 断面積の増加に伴って研削抵抗が増加しているが，ダイ ヤモンドの目ずまりが原因と思われる.ダイヤモンド砥
石で鉄を研削することは特に目ずまりが激しいので不適 当とされているが，アルミナ-鉄複合体では鉄とアルミ ナを交互に研削していることになり，鉄による目ずまり がある程度防止されていると考えられる.

鉄を添加したことで予想される，そのほかの材質的な 変化として, 化学的耐食性, 耐熱性等の劣化が予想され る. 鉄 $20 \mathrm{wt} \%$ 添加のアルミナについて，5\%の沸騰硫 酸で処理したが，最初の数分で若干の鉄の溶出が認めら れるのみで，それ以降はほとんど変化しない，試料表面 の鉄は侵されるものの, 内部の鉄粒子は完全にアルミナ 中にとじ込められているので, 複合体の化学的安定性は アルミナ単味と同等と言えるであろう，高温曲げ強度も $600^{\circ} \mathrm{C}$ 程度までは，一般のアルミナに比較しうる値を示 している.

\section{5. 総 括}

アルミナと鉄の粉末を混合し，ホットプレス法により 複合焼結体を作製し，その各種特性について検討した。 その結果は以下のとおりである.

（1）アルミナ-鉄複合体の最適ホットプレス温度は $1550^{\circ} \mathrm{C}$ 程度である。

（2）鉄添加量が 20 wt\% まではほぼ理論密度までち 密化するが，それ以上では相対密度が次第に低下する。

（3）複合体中では単味に比べてアルミナの粒成長が 大きく，また鉄粒子のまわりには熱膨張差による空間が 存在する.

（4）X 線回折によると，焼結体中の鉄とアルミナ の反応は認められない.

（5）破壊靶性は鉄添加量とともに増加し，鉄 50 wt $\%$ では $K_{\mathrm{IC}}=4 \mathrm{MN} / \mathrm{m}^{3 / 2}$ 近くに達する。

（6）ビッカース硬度は鉄 $10 \mathrm{wt} \%$ 添加あたりで急速 な低下を示し，それ以上でもやや低下の傾向にある。

（7）アルミナ焼結体ディスクに対する比摩耗量は, 鉄添加量とともに増加するが，鉄 $40 \mathrm{wt} \%$ までは窒化ケ イ素に匹敵する $10^{-7} \mathrm{~mm}^{2} / \mathrm{kgf}$ 以下の比摩耗量である.

（8）研削抵抗は鉄を添加することによりかなり減少 し，特に，鉄 $30 \mathrm{wt} \%$ 複合体の接線方向の研削抵抗はア ルミナ単味の $1 / 10$ 程度まで低下した.

（9）鉄 $20 \mathrm{wt} \%$ 複合体の沸騰硫酸による腐食試験で は，最初の数分間に表面の鉄が溶出するのみで，それ以 降はほとんど変化しない。

（10）鉄 $20 \mathrm{wt} \%$ 複合体の高温強度は， $600^{\circ} \mathrm{C}$ までは 徐々に，それ以上の温度ではやや急速に低下する。

\section{文献}

1）奥田 博，“第 4 回次世代産業技術シンポジウム—ファ インセラミックス——”，日本産業技術振興協会（1986） pp. $229-38$.

2）小泉光恵，材料， 36，313-19（1987）. 
3）上垣外修己, 日本金属学会会報, 24, 480-84（1985）.

4) 木下 実, 松村治行, 岩佐美喜男, 速水諒三, 窯協, 89, 302-09 (1981).

5) J. J. Petrovic, L. A. Jacobson, P.K. Talty and A.K. Vasudevan, J. Am. Ceram. Soc., 58, 113-16 (1975).
6）岩佐美喜男, 近藤 功, 渡辺隆司, 窐協, 94, 1081-86(1986).

7）岩佐美熹男, 樋端保夫, 窯協, 94, 336-43 (1986).

8）松井正己，機械の研究，38，373-79 (1986).

9）岩佐美喜男, 樋端保夫, 吉村 茂, 小林英一, 窯協, 93, 73-80 (1985). 